\title{
Effect of Budload and Fertilizer Application on Leaf Petiole and Fruit Nutrient Status of Grape cv. Sahebi
}

\author{
Aroosa Khalil", M.K. Sharma, Nowsheen Nazir and Rifat Bhat \\ Division of Fruit Science, Sher-e-Kashmir University of Agricultural Sciences and Technology \\ of Kashmir, Srinagar 190025, Jammu and Kashmir, India \\ *Corresponding author
}

\begin{tabular}{|l|}
\hline Ke y w o r d s \\
Grape, Nutrients, \\
Fertilizer, Budload \\
\hline Article Info \\
\hline $\begin{array}{l}\text { Accepted: } \\
\text { 06 May } 2018 \\
\text { Available Online: } \\
\text { 10 June } 2018\end{array}$ \\
\hline
\end{tabular}

\section{A B S T R A C T}

The studies on the influence of bud load and fertilizer application on leaf petiole and fruit nutrient status of grape cv. 'Sahebi' was carried out in Model grapevine orchard of Department of Horticulture at Kralbagh, Tehsil Lar Distt. Ganderbal (J\&K) for two consecutive years. The treatment consisted of 3 levels of budload viz. $B_{1}$ (96 buds/vine), $B_{2}$ (128 buds/ vine) and $B_{3}$ (160 buds/vine), 3 levels of fertilizer doses viz. $\mathrm{F}_{1}$ (FYM $50 \mathrm{~kg} / \mathrm{vine}+$ recommended dose of NPK: 555, 227, 470g/vine), $F_{2}$ (FYM $50 \mathrm{~kg} / \mathrm{vine}+2$ times recommended dose of NPK: 1110, 454, 940g/vine), $\mathrm{F}_{3}$ (FYM $50 \mathrm{~kg} / \mathrm{vine}+3$ times recommended dose of NPK: 1665, 681, $1410 \mathrm{~g} / \mathrm{vine})$ and their combinations. Budload $\mathrm{B}_{1}$ recorded highest leaf petiole $(1.62$ and $1.66 \%)$ and fruit $(1.184$ and $1.302 \%) \mathrm{N}$ content while as bud load $\mathrm{B}_{2}$ noticed highest leaf petiole $(0.475$ and $0.470 \%)$ and fruit $(0.068$ and $0.072 \%) \mathrm{P}$ content as well as leaf petiole $(2.31$ and $2.41 \%)$ and fruit $(0.535$ and $0.562 \%) \mathrm{K}$ contents. Maximum leaf petiole (1.38 and $1.31 \%)$ and fruit $(0.038$ and $0.041 \%) \mathrm{Ca}$ content was observed in budload $\mathrm{B}_{3}$. However budload showed no significant difference with respect to leaf petiole and fruit $\mathrm{Zn}$ content. Leaf petiole $\mathrm{B}$ (46.62 and $48.53 \mathrm{ppm})$ and fruit $\mathrm{B}(9.00$ and $9.54 \mathrm{ppm})$ were highest with $\mathrm{B}_{3}$ and $\mathrm{B}_{2}$, respectively. Fertilizer level $\mathrm{F}_{3}$ registered highest percentage of leaf petiole $(1.60$ and $1.63 \%)$ and fruit $(1.083$ and $1.158 \%) \mathrm{N}$ content. However fertilizer level $\mathrm{F}_{2}$ recorded maximum leaf petiole $(0.419$ and $0.447 \%)$ and fruit $(0.063$ and $0.068 \%)$ $\mathrm{P}$, leaf petiole (1.98 and $2.09 \%)$ and fruit $(0.492$ and $0.482 \%) \mathrm{K}$ contents and fruit $\mathrm{Ca}(0.036$ and $0.038 \%), \mathrm{B}(8.77$ and $9.14 \%)$ and $\mathrm{Zn}(1.43$ and $1.46 \%)$ contents respectively. Fertilizer level $\mathrm{F}_{1}$ resulted in highest content of leaf petiole $\mathrm{Ca}(1.30$ and $1.32 \%$ ), B (43.73 and $45.58 \mathrm{ppm}$ ) and $\mathrm{Zn}$ (48.92 and $46.09 \mathrm{ppm}) . \mathrm{B}_{1} \mathrm{~F}_{3}$ interaction resulted in highest leaf petiole and fruit $\mathrm{N}$ content. Leaf petiole $\mathrm{P}$ and $\mathrm{K}$ and fruit $\mathrm{P}, \mathrm{K}, \mathrm{Ca}$ and $\mathrm{B}$ contents were highest with $\mathrm{B}_{2} \mathrm{~F}_{2}$. Leaf petiole $\mathrm{Ca}, \mathrm{B}$ and $\mathrm{Zn}$ and fruit $\mathrm{Zn}$ content were highest with $\mathrm{B}_{3} \mathrm{~F}_{1}$. Therefore it can be concluded that budload, $\mathrm{B}_{2}\left(128\right.$ buds/vine) and fertilizer dose, $\mathrm{F}_{2}$ (FYM-50 kg/vine +2 times recommended dose-NPK: $1110,454,940 \mathrm{~g} / \mathrm{vine}$ ) proved to be the best in improving leaf and fruit nutrient status of grape. 


\section{Introduction}

Grape (Vitis vinifera L.) being one of the important fruit crops of temperate zone, has acclimatized to sub-tropical and tropical agro climatic conditions prevailing in the Indian sub-continent. Being a refreshing fruit, rich in sugars, acids, minerals, vitamins and tannins, it can be eaten raw or can be used for making jam, juice, jelly, vinegar, wine, grape seed extracts, raisins, molasses and grape seed oil. Major grape growing states are Maharashtra, Karnataka, Andhra Pradesh, Punjab and Tamil Nadu. In Jammu and Kashmir, grapes are grown in an area of 321 hectares with a production of 648 MT (Anon, 2017) but the productivity of grape vines had been declining and has come down to a very low level. Further quality of grape is also poor when compared to other grape growing states of India. The possible reason is non-adoption of proper management practices particularly pruning and fertilizer application. The productivity and quality of grapes is dependent mainly on perfect pruning and proper fertilization. Grape is a heavy feeder of nutrients. Three of the major elements i.e. N, $\mathrm{P}, \mathrm{K}$ are removed from the soil in large amounts. Deficiency of nutrients causes poor growth, yield and quality of fruits (Kumar et al., 2015 and Mishra et al., 2016). Therefore, it is necessary to apply the nutrients through manures and fertilizers to meet the growth and reproductive needs of the grapevine. Moreover the application of nutrients affect the leaf and fruit nutrient status of the crop and the plant tissue analysis is commonly accepted as being the most reliable guide for evaluating the success of the orchard fertility programme. Supplying the nutrient need to the tree crops is critical to achieve consistent production of high quality fruits. The main grape growing belt of Kashmir valley is district Ganderbal and Sahebi is the predominating variety of the area but grape vines in the area are not being maintained on the scientific lines with respect to pruning, application of nutrients and other cultural techniques thus resulting in low yields of poor quality berries. So there is a need to rejuvenate these old grape vines by means of maintenance of bud load and nutrient dose so that leaf petiole and fruit nutrient status in grapes can be improved for better yield and quality. Keeping all these aspects in mind, the present investigation was undertaken with the objective to study the leaf and fruit nutrient status of grape as affected by budload and fertilizer application

\section{Materials and Methods}

These investigations were carried out to assess the influence of bud load, fertilizer levels and their combinations on leaf petiole and fruit nutrient status of grape cv. 'Sahebi' in Model grapevine orchard of Department of Horticulture at Kralbagh, Tehsil Lar, District Ganderbal (J\&K) for two consecutive years. The treatment consisted of 3-levels of budload $\left(\mathrm{B}_{1}-96\right.$ buds/vine, $\mathrm{B}_{2}-128$ buds/ vine and $\mathrm{B}_{3}$ 160 buds/vine), 3-levels of fertilizer doses $\left(\mathrm{F}_{1}=\mathrm{FYM} 50 \mathrm{~kg} / \mathrm{vine}+\right.$ Recommended dose of NPK: 555, 227， 470g/vine, $\mathrm{F}_{2}=\mathrm{FYM} 50$ $\mathrm{kg} / \mathrm{vine}+2$ times recommended dose of NPK: $1110,454,940 \mathrm{~g} /$ vine, $\mathrm{F}_{3}=\mathrm{FYM} 50 \mathrm{~kg} / \mathrm{vine}+3$ times recommended dose of NPK: 1665, 681, $1410 \mathrm{~g} / \mathrm{vine})$ and their combinations replicated thrice with a double plot size in a completely randomized block design. Data on leaf petiole $\mathrm{N}, \mathrm{P}, \mathrm{K}, \mathrm{Ca}, \mathrm{B}$ and $\mathrm{Zn}$ contents and fruit N, P, $\mathrm{K}, \mathrm{Ca}, \mathrm{B}$ and $\mathrm{Zn}$ contents was recorded. For estimation of leaf petiole and fruit nitrogen, the sample was digested in mixture containing potassium sulphate, ferrous sulphate and copper sulphate in the ratio of 10:1:5 in sulphuric acid and total nitrogen was determined by Micro-Kjeldahl's method (Jackson, 1973). For estimation of leaf petiole and fruit $\mathrm{P}, \mathrm{K}, \mathrm{Ca}$ and $\mathrm{Zn}$, samples were digested with di-acid mixture consisting of nitric acid and perchloric acid (9:4 ratio). Phosphorus was estimated by vanado- 
molybdo phosphoric yellow colour method (Jackson, 1973). Potassium content in leaf petiole and fruit samples was determined with flame photometry technique. The calcium content was estimated by E.D.T.A. method as described by Jackson (1973). Zinc was determined using Atomic Absorption Spectrophotometer. For the estimation of boron, dry ashing of the leaf petiole and fruit samples was done at $550^{\circ} \mathrm{C}$ for three hours and the ash was taken in $10 \mathrm{ml}$ of $6.5 \mathrm{~N} \mathrm{HCl}$ (Chapman and Pratt, 1961). Boron was then determined by Carmine method (Hatcher and Wilcox, 1950). The data generated were subjected to statistical analysis as per the procedures described by Gomez and Gomez (1984).

\section{Results and Discussion}

\section{Leaf petiole nutrient status}

Bud load, fertilizer doses and their interactions appreciably influenced leaf petiole $\mathrm{N}, \mathrm{P}, \mathrm{K}$, $\mathrm{Ca}, \mathrm{B}$ and $\mathrm{Zn}$ contents (Table 1). Significantly highest percentage of leaf petiole $\mathrm{N}$ was recorded with $\mathrm{B}_{1}(1.62$ and $1.66 \%)$ and $\mathrm{F}_{3}$ (1.60 and $1.63 \%)$ in comparison to other bud load and fertilizer doses. Among bud load and fertilizer dose combination, highest leaf petiole $\mathrm{N}$ content was recorded with $\mathrm{B}_{1} \mathrm{~F}_{3}$ (1.69 and $1.74 \%$ ). Nitrogen is allocated preferentially to the more exposed leaves which appeared at light budload. Shoeib and El-Sayed (2004) also observed that there was a gradual and significant reduction in percentage of $\mathrm{N}$ in leaf petioles of Thompson Seedless grape with increasing vine load levels from 72-108 buds/vine. These results are also in line with the findings of Shalan (2013). The highest increase in $\mathrm{N}$ content of leaf petioles with higher dose of fertilizers which might be due to increase in $\mathrm{N}$ supply which render more $\mathrm{N}$ available to the plant and its efficient translocation under high supply from root to other parts of tree could have aided to its enhanced accumulation in leaves. The results are in conformity with the findings of Abd El-Razek et al., (2011).

Maximum leaf petiole $\mathrm{P}(0.475$ and $0.470 \%)$ was recorded in vines pruned to $\mathrm{B}_{2}$ and with fertilizer level $\mathrm{F}_{2} \quad(0.419$ and $0.447 \%)$. Combination of $\mathrm{B}_{2} \mathrm{~F}_{2}$ registered maximum leaf petiole $\mathrm{P}(0.505$ and $0.520 \%)$ in comparison to other bud load and fertilizer doses during both the years, respectively. This might be due to enhanced rate of phosphorus application which leads to its greater mobility and hence absorption by the plant roots and hence the corresponding increase in plant leaves. These findings are in agreement with Mehmood (2003). Decrease in leaf petiole phosphorus content with higher level of nitrogen and potassium could possibly be due to antagonism of nitrogen and potassium with phosphorus. These results are also in agreement with Kaith (1992), Kaith and Awasthi (1998).

Highest leaf petiole $\mathrm{K}$ content was recorded with budload $\mathrm{B}_{2}(2.31$ and $2.41 \%)$ and fertilizer level $F_{2}$ (1.98 and $\left.2.09 \%\right)$. The combined influence of budload and fertilizer dose also had significant influence on leaf petiole $\mathrm{K}$ content which was maximum under $\mathrm{B}_{2} \mathrm{~F}_{2}$ during both the years (2.47 and $2.57 \%$ ).

Medium budload $\mathrm{B}_{2}$ (128 buds/vines) recorded the highest leaf petiole and fruit $\mathrm{K}$ content which may be due to less accumulation of dry matter and optimum vegetative growth. Similar results have been confirmed by Shalan (2013). Fertilizer dose $F_{2}$ registered maximum leaf petiole $\mathrm{K}$ content. Increasing the nitrogen level results in the decrease of leaf petiole $\mathrm{K}$ content. This is due to the existence of antagonism between nitrogen and potassium. However, increasing potassium level increases leaf petiole and fruit potassium. Since potassium is mobile, its effective translocation to leaves and fruits could have aided its 
accumulation in leaves. It is also due to the fact that higher levels of soil potassium application create a concentration gradient between potassium ion concentration inside the root and soil solution, which ultimately resulted in increased uptake of potassium by the plants. Also potassium is involved in enhancing the permeability of leaf cells which account for an accumulation of more potassium. The results are in conformity with those of Rather (2006) and Abd El-Razek et al., (2011).

Leaf petiole $\mathrm{Ca}$ content was significantly affected by bud load and fertilizer dose during both the years of study however the interaction between both was non-significant. Budload $\mathrm{B}_{3}$ had maximum leaf petiole $\mathrm{Ca}$ content (1.38 and $1.31 \%)$ in comparison to other bud load levels. Significantly higher leaf petiole $\mathrm{Ca}$ content (1.30 and $1.32 \%)$ was observed in fertilizer level $F_{1}$. Among the budload and fertilizer level interaction, $\mathrm{B}_{3} \mathrm{~F}_{1}$ recorded highest leaf petiole $\mathrm{Ca}$ content $(1.42$ and $1.38 \%$ ) during both the years of study. Vines with a high ( $\mathrm{B}_{3}-160$ buds/vine) and medium $\left(\mathrm{B}_{2}-128\right.$ buds/vine $)$ budload accumulated highest content of leaf petiole calcium. The decrease in leaf petiole calcium with decrease in budload could be attributed to higher potassium levels in the leaf petioles of vines with a light budload. These results are in line with the findings of Singh and Singh (2002) and Rather (2006). Phosphorus application has no significant effect on $\mathrm{Ca}$ content in leaves (Singh, 2010). Application of potassium fertilizer to the soil decreases the calcium content of leaves and fruits mainly because of inverse relationship between availability of potassium in soil and calcium content of leaf and fruit. These findings are in harmony with Singh (1982) and Rather (2006).

Leaf petiole $\mathrm{B}$ content was significantly affected by bud load and fertilizer dose during both the years of study. Budload $\mathrm{B}_{3}$ had maximum leaf petiole content (46.62 and $48.53 \mathrm{ppm}$ ) in comparison to other bud load levels. Significantly higher leaf petiole B content (43.73 and $45.58 \mathrm{ppm}$ ) was observed in fertilizer level $F_{1}$. Among the budload and fertilizer level interaction, $\mathrm{B}_{3} \mathrm{~F}_{1}$ recorded highest leaf petiole $\mathrm{B}$ content (50.22 and 54.64 $\mathrm{ppm}$ ) during both the years of study. High boron with fertilizer level $F_{1}$ may be due to the reason that heavy nitrogen fertilization significantly reduces boron content of leaves, heavy phosphate fertilization reduces boron slightly whereas application of potash fertilizers has no effect on boron and the results are in accordance to that of Labanauskas et al., (1958).

Zn content in the grape leaf petiole was not significantly affected by bud load however it was significantly influenced by fertilizer dose during both the years of study though the interaction between both was also nonsignificant. Budload $\mathrm{B}_{3}$ had maximum leaf petiole $\mathrm{Zn}$ content (48.70 and $46.29 \mathrm{ppm}$ ) in comparison to other bud load levels.

Significantly higher leaf petiole $\mathrm{Zn}$ content (48.92 and $46.09 \mathrm{ppm}$ ) was observed with fertilizer level $F_{1}$. Among the budload and fertilizer level interaction, $\mathrm{B}_{3} \mathrm{~F}_{1}$ recorded highest leaf petiole $\mathrm{Zn}$ content (51.28 and $49.35 \mathrm{ppm}$ ) during both the years of study. Heavy nitrogen and phosphorus fertilization is known to reduce the zinc content whereas potassium fertilizers have no effect on zinc (Kanwar, 1978).

\section{Fruit nutrient status}

Effect of bud load, fertilizer dose and their interaction on fruit $\mathrm{N}, \mathrm{P}, \mathrm{K}, \mathrm{Ca}, \mathrm{B}$ and $\mathrm{Zn}$ contents is given in Table 2. Highest fruit $\mathrm{N}$ content (1.184 and $1.302 \%)$ was recorded in vines pruned to $B_{1}$ and with fertilizer level $F_{3}$ (1.083 and $1.158 \%)$. 
Table.1 Effect of bud load, fertilizer levels and their combinations on leaf petiole nutrient status of grape cv. Sahebi

\begin{tabular}{|c|c|c|c|c|c|c|c|c|c|c|c|c|}
\hline \multirow[t]{2}{*}{ Treatments } & \multicolumn{2}{|c|}{$\begin{array}{l}\text { Petiole N } \\
(\%)\end{array}$} & \multicolumn{2}{|c|}{ Petiole P (\%) } & \multicolumn{2}{|c|}{$\begin{array}{l}\text { Petiole K } \\
(\%)\end{array}$} & \multicolumn{2}{|c|}{$\begin{array}{l}\text { Petiole Ca } \\
(\%)\end{array}$} & \multicolumn{2}{|c|}{$\begin{array}{l}\text { Petiole B } \\
\text { (ppm) }\end{array}$} & \multicolumn{2}{|c|}{$\begin{array}{l}\text { Petiole Zn } \\
(\mathrm{ppm})\end{array}$} \\
\hline & $\begin{array}{l}1^{\text {st }} \\
\text { year }\end{array}$ & $\begin{array}{l}2^{\text {nd }} \\
\text { year }\end{array}$ & $\begin{array}{l}1^{\mathrm{st}} \\
\text { year }\end{array}$ & & $\begin{array}{l}1^{\text {st }} \\
\text { year }\end{array}$ & $\begin{array}{l}2^{\text {nd }} \\
\text { year }\end{array}$ & $\begin{array}{l}1^{\text {st }} \\
\text { year }\end{array}$ & $\begin{array}{l}2^{\text {nd }} \\
\text { year }\end{array}$ & $\begin{array}{l}1^{\text {st }} \\
\text { year }\end{array}$ & $\begin{array}{l}2^{\text {nd }} \\
\text { year }\end{array}$ & $\begin{array}{l}1^{\text {st }} \\
\text { year }\end{array}$ & $\begin{array}{l}2^{\text {nd }} \\
\text { year }\end{array}$ \\
\hline$B_{1}$ & 1.62 & 1.66 & 0.384 & 0.444 & 1.87 & 1.92 & 1.12 & 1.18 & 31.38 & 32.11 & 46.16 & 43.75 \\
\hline$B_{2}$ & 1.53 & 1.56 & 0.475 & 0.470 & 231 & 2.41 & & 1.26 & 41.54 & & 44.17 & 41.13 \\
\hline $\mathbf{B}_{3}$ & 1.45 & 1.47 & 0.317 & & 1.26 & 1.39 & 1.38 & 1.31 & 46.62 & & 48.70 & 46.29 \\
\hline $\mathbf{C D}_{(0.05)}$ & .05 & 0.07 & 0.032 & 013 & 0.13 & & 0.18 & 0.05 & 3.31 & & NS & NS \\
\hline$\overline{F_{1}}$ & & 1.46 & 0.363 & 0.392 & 1.64 & 1.71 & & 1.32 & 43.73 & & & 46.09 \\
\hline$\overline{F_{2}}$ & & 1.59 & 0.419 & & 1. & & & & 41.56 & & 46.76 & 43.47 \\
\hline$F_{3}$ & 60 & 1.63 & 0.393 & 0.41 & 1.8 & 1.5 & 1.1 & & 34.26 & 33. & 43.35 & 41.61 \\
\hline $\mathbf{C D}_{(0.05)}$ & 0.02 & 0.02 & 0.014 & 0.016 & 0.12 & 0.016 & 0.06 & 0.05 & 2.42 & 4.72 & 2.32 & 2.79 \\
\hline $\mathrm{B}_{1} \mathrm{~F}_{1}$ & 1.53 & 1.56 & 0.354 & & 1.7 & 1.76 & 1.18 & 1.25 & 34.56 & & 49.00 & 46.12 \\
\hline $\mathbf{B}_{1} \mathbf{F}_{2}$ & 1.64 & 1.68 & 0.413 & 0.445 & 2.00 & 2.08 & 1. & 1.21 & 32.11 & 34. & 45.22 & 43.81 \\
\hline $\mathrm{B}_{1} \mathrm{~F}_{3}$ & 1.69 & 1.74 & 0.384 & 0.480 & 1.8 & 1.9 & 1 & 1.07 & 27.47 & 25.52 & 44.25 & 41.32 \\
\hline $\mathbf{B}_{2} \mathbf{F}_{1}$ & & & & & & & & & 46.40 & & 46.49 & 42.79 \\
\hline $\mathrm{B}_{2} \mathrm{~F}_{2}$ & & & & & & & & & 43.91 & & & 41.34 \\
\hline $\mathbf{B}_{2} F_{3}$ & & 1.63 & 0.475 & 0.429 & 2.31 & 2.41 & 1.15 & 1.15 & 34.33 & 31.73 & 41.73 & 39.25 \\
\hline $\mathbf{B}_{3} \mathbf{F}_{1}$ & 1.37 & 1.6 & 0.293 & 0.06 & 1.04 & 1.12 & 1.42 & 1.38 & 50.22 & 54.64 & 51.28 & 49.35 \\
\hline $\mathbf{B}_{3} \mathbf{F}_{2}$ & 1.48 & 1.51 & 0.339 & 0.376 & 1.47 & 1.62 & 1.39 & 1.35 & 48.66 & 47.28 & 50.76 & 45.26 \\
\hline $\mathbf{B}_{3} F_{3}$ & & 1.53 & 0.320 & & 1.2 & 1.43 & 1.33 & 1.23 & 40.98 & 43.67 & 44.07 & 44.25 \\
\hline $\mathrm{CD}_{(0.05)}$ & 0.09 & 0.08 & 0.040 & 0.030 & 0.17 & 0.03 & NS & NS & 3.76 & 5.51 & NS & NS \\
\hline
\end{tabular}

Table.2 Effect of bud load, fertilizer levels and their combinations on fruit nutrient status of grape cv. Sahebi

\begin{tabular}{|c|c|c|c|c|c|c|c|c|c|c|c|c|}
\hline \multirow[t]{2}{*}{ Treatments } & \multicolumn{2}{|c|}{ Fruit N (\%) } & \multicolumn{2}{|c|}{ Fruit P (\%) } & \multicolumn{2}{|c|}{ Fruit K (\%) } & \multicolumn{2}{|c|}{ Fruit Ca (\%) } & \multicolumn{2}{|c|}{ Fruit B (ppm) } & \multicolumn{2}{|c|}{ Fruit Zn (ppm) } \\
\hline & $\begin{array}{l}1^{\text {st }} \\
\text { year }\end{array}$ & $\begin{array}{l}2^{\text {nd }} \\
\text { year }\end{array}$ & $\begin{array}{l}1^{\text {st }} \\
\text { year }\end{array}$ & $\begin{array}{l}2^{\text {nd }} \\
\text { year }\end{array}$ & $\begin{array}{l}1^{\text {st }} \\
\text { year }\end{array}$ & $\begin{array}{l}2^{\text {nd }} \\
\text { year }\end{array}$ & $\begin{array}{l}1^{\text {st }} \\
\text { year }\end{array}$ & $\begin{array}{l}2^{\text {nd }} \\
\text { year }\end{array}$ & $\begin{array}{l}1^{\text {st }} \\
\text { year }\end{array}$ & $\begin{array}{l}2^{\text {nd }} \\
\text { year }\end{array}$ & $\begin{array}{l}1^{\text {st }} \\
\text { year }\end{array}$ & $\begin{array}{l}2^{\text {nd }} \\
\text { year }\end{array}$ \\
\hline$B_{1}$ & 1.184 & 1.302 & 0.059 & 0.062 & 0.478 & 0.450 & 0.028 & 0.031 & 8.27 & 8.57 & 1.28 & 1.31 \\
\hline $\mathbf{B}_{2}$ & 1.031 & 1.080 & 0.068 & 0.072 & 0.535 & 0.562 & 0.038 & 0.041 & 9.00 & 9.54 & 1.23 & 1.23 \\
\hline $\mathbf{B}_{3}$ & 0.846 & 0.868 & 0.051 & 0.054 & 0.378 & 0.343 & 0.033 & 0.035 & 8.66 & 8.90 & 1.38 & 1.41 \\
\hline $\mathrm{CD}_{(0.05)}$ & 0.050 & 0.100 & 0.003 & 0.004 & 0.015 & 0.012 & 0.001 & 0.003 & 0.21 & 0.24 & NS & NS \\
\hline$F_{1}$ & 0.958 & 1.014 & 0.056 & 0.059 & 0.437 & 0.417 & 0.032 & 0.36 & 8.65 & 9.05 & 1.29 & 1.32 \\
\hline$\overline{F_{2}}$ & 1.020 & 1.077 & 0.063 & 0.068 & 0.492 & 0.482 & 0.036 & 0.038 & 8.77 & 9.14 & 1.43 & 1.46 \\
\hline$F_{3}$ & 1.083 & 1.158 & 0.060 & 0.063 & 0.463 & 0.455 & 0.030 & 0.033 & 8.51 & 8.82 & 1.17 & 1.19 \\
\hline $\mathbf{C D}_{(0.05)}$ & 0.010 & 0.010 & 0.001 & 0.003 & 0.020 & 0.010 & 0.003 & 0.001 & 0.17 & 0.19 & 0.07 & 0.09 \\
\hline $\mathrm{B}_{1} \mathrm{~F}_{1}$ & 1.126 & 1.226 & 0.056 & 0.060 & 0.456 & 0.410 & 0.027 & 0.031 & 8.26 & 8.76 & 1.28 & 1.30 \\
\hline $\mathbf{B}_{1} \mathbf{F}_{2}$ & 1.180 & 1.300 & 0.062 & 0.065 & 0.500 & 0.480 & 0.031 & 0.034 & 8.40 & 8.50 & 1.37 & 1.40 \\
\hline $\mathrm{B}_{1} \mathbf{F}_{3}$ & 1.246 & 1.380 & 0.058 & 0.065 & 0.480 & 0.460 & 0.025 & 0.028 & 8.15 & 8.46 & 1.20 & 1.25 \\
\hline $\mathbf{B}_{2} \mathbf{F}_{1}$ & 0.980 & 1.016 & 0.063 & 0.066 & 0.506 & 0.523 & 0.036 & 0.041 & 8.99 & 9.50 & 1.22 & 1.23 \\
\hline $\mathrm{B}_{2} \mathrm{~F}_{2}$ & 1.030 & 1.073 & 0.073 & 0.081 & 0.570 & 0.603 & 0.042 & 0.045 & 9.14 & 9.72 & 1.44 & 1.47 \\
\hline $\mathrm{B}_{2} \mathrm{~F}_{3}$ & 1.083 & 1.150 & 0.069 & 0.071 & 0.530 & 0.560 & 0.035 & 0.38 & 8.89 & 9.40 & 1.04 & 1.01 \\
\hline $\mathbf{B}_{3} \mathbf{F}_{1}$ & 0.770 & 0.800 & 0.048 & 0.052 & 0.350 & 0.320 & 0.032 & 0.35 & 8.70 & 8.89 & 1.38 & 1.43 \\
\hline $\mathbf{B}_{3} \mathbf{F}_{2}$ & 0.850 & 0.860 & 0.054 & 0.059 & 0.406 & 0.363 & 0.037 & 0.36 & 8.79 & 9.21 & 1.48 & 1.52 \\
\hline $\mathbf{B}_{3} \mathbf{F}_{3}$ & 0.920 & 0.946 & 0.052 & 0.054 & 0.380 & 0.346 & 0.031 & 0.033 & 8.51 & 8.60 & 1.27 & 1.30 \\
\hline $\mathrm{CD}_{(0.05)}$ & NS & NS & 0.005 & 0.006 & NS & NS & 0.005 & 0.004 & NS & NS & 0.10 & 0.11 \\
\hline
\end{tabular}


Combination of $\mathrm{B}_{1} \mathrm{~F}_{3}$ registered maximum fruit $\mathrm{N}$ content (1.246 and $1.380 \%)$ in comparison to other bud load and fertilizer doses during both the years, respectively. Dejong and Doyle (1985) also observed that nitrogen correlate positively with photosynthetic capacity presumably because of a greater incorporation of nitrogen into leaf cellular proteins such as ribulose biphosphate carboxylase under high light. Since the photosynthetic capacity of grape leaves is influenced by light environment and the nitrogen is allocated preferentially to the more exposed leaves which appeared at light budload. The results are also in line with the findings of Shalan (2013). Highest increase in fruit $\mathrm{N}$ content with fertilizer dose $\mathrm{F}_{3}$ might be due to increase in $\mathrm{N}$ supply which render more $\mathrm{N}$ available to the plant and its efficient translocation under high supply from root to other parts of tree could have aided to its enhanced accumulation in leaves and fruits. The results are in conformity with the findings of Abd El-Razek et al., (2011).

Among bud load treatments, highest fruit $\mathrm{P}$ content $(0.068$ and $0.072 \%)$ was recorded with budload $\mathrm{B}_{2}$. Among fertilizer levels, highest fruit $\mathrm{P}$ content $(0.063$ and $0.068 \%)$ was recorded with fertilizer dose $F_{2}$. Combination of $\mathrm{B}_{2} \mathrm{~F}_{2}$ resulted in highest fruit $\mathrm{P}$ content $(0.073$ and $0.081 \%)$ during both the years under study. This might be due to enhanced rate of phosphorus application which leads to its greater mobility and hence absorption by the plant roots and hence the corresponding increase in plant leaves. These findings are in agreement with Shalan (2013).

Highest fruit $\mathrm{K}$ content (0.535 and $0.562 \%)$ was recorded with budload $\mathrm{B}_{2}$. Among fertilizer levels, highest fruit K content (0.492 and $0.482 \%$ ) was recorded with fertilizer level $\mathrm{F}_{2}$. Combination of $\mathrm{B}_{2} \mathrm{~F}_{2}$ resulted in highest fruit $\mathrm{K}$ content $(0.570$ and $0.603 \%)$ during both the years of study. Medium budload $\mathrm{B}_{2}$ (128 buds/vines) recorded the highest fruit $\mathrm{K}$ content which may be due to less accumulation of dry matter and optimum vegetative growth. Similar results have been confirmed by Shalan (2013). Fertilizer dose $\mathrm{F}_{2}$ registered maximum fruit $\mathrm{K}$ content. However, increasing potassium level increases fruit potassium. Also phosphorus and potassium are involved in doubling the permeability of leaf cells which account for an accumulation of more potassium. The results are in conformity with those of Abd El-Razek (2011).

Highest fruit Ca content (0.038 and $0.041 \%)$ was recorded with budload $\mathrm{B}_{2}$. Among fertilizer levels, highest fruit $\mathrm{Ca}$ content $(0.036$ and $0.038 \%)$ was recorded with $\mathrm{F}_{2}$. Combination of $\mathrm{B}_{2} \mathrm{~F}_{2}$ resulted in highest fruit Ca content $(0.042$ and $0.045 \%)$ during both the years under study. Vines with a high $\left(\mathrm{B}_{3^{-}}\right.$ 160 buds/vine) and medium ( $\mathrm{B}_{2}-128$ buds/vine) budload accumulated highest content of leaf petiole and fruit calcium. The decrease in leaf petiole and fruit calcium with decrease in budload could be attributed to higher potassium levels in the leaf petioles of vines with a light budload. These results are in line with the findings of Rather (2006). Application of increased dose of fertilizer decreased the calcium content in the leaf petioles and fruits. The failure of nitrogen application to increase the calcium content in leaf petiole and fruit may be related to the slow mobility of calcium in plant tissues. These findings are in harmony with Rather (2006).

Maximum fruit B content $(9.00$ and 9.54 ppm) was recorded with budload $B_{2}$. Among fertilizer levels, highest fruit B content $(8.77$ and $9.14 \mathrm{ppm}$ ) was recorded with $F_{2}$. Combination of $\mathrm{B}_{2} \mathrm{~F}_{2}$ interaction though not significantly influenced fruit $\mathrm{B}$ content but resulted in highest fruit B content (9.14 and $9.72 \mathrm{ppm}$ ) during both the years of study. 
Fruit boron content was found to be maximum in vines with the application of low fertilizer dose, $F_{1}$ as heavy nitrogen fertilization significantly reduces boron content of leaves, heavy phosphate fertilization reduces boron slightly whereas application of potash fertilizers has no effect on boron. The results are in conformity with the findings of Labanauskas et al., (1958).

Fruit $\mathrm{Zn}$ content was not significantly influenced by budload however it was highest (1.38 and $1.41 \mathrm{ppm}$ ) with budload $\mathrm{B}_{2}$. Significantly higher fruit $\mathrm{Zn}$ content was recorded with fertilizer levels $\mathrm{F}_{2}$ (1.43 and $1.46 \mathrm{ppm}$ ) and combination of $\mathrm{B}_{3} \mathrm{~F}_{2}$ (1.48 and $1.52 \mathrm{ppm})$. Highest content of fruit zinc with medium fertilizer dose is also reported by Kanwar (1978).

\section{References}

Abd El-Razek, E., Treutter, D., Saleh, M.M.S., El-Shammaa, M., Fouad, A.A. and Abdel-Hamid, N. (2011) Effect of nitrogen and potassium fertilization on productivity and fruit quality of Crimson Seedless grape. Agriculture and Biology Journal of North America 2(2): 330-340.

Anonymous. (2017) District wise/kind wise area and production of major horticultural crops in Jammu and Kashmir state for the year 2016-17. Department of Horticulture, Jammu and Kashmir Government.

Chapman, H.D. and Pratt, P.F. (1961) Methods of analysis for soils, plants and water. University of California, Division of Agricultural Science Manual: 25-53 p.

Dejong, T.M. and Doyle, J.F. (1985) Seasonal relationships between leaf nitrogen content (photosynthetic capacity) and leaf canopy light exposure in peach. Plant Cell and Environment 8: 701-706.
Gomez, K.A. and Gomez, A.A. (1984) Statistical Proceedings for Agriculture Research ( $2^{\text {nd }}$ edn.). John Wiley and Sons Inc., New York.

Hatcher, J.T. and Wilcox, L.V. (1950) Colorimetric determination of boron using carmine. Analytical Chemistry 22: 567-569.

Jackson, M.L. (1973) Soil Chemical Analysis. Prentice Hall of India Private Limited, New Delhi, pp. 38-82.

Kaith, N.S. (1992) Potassium nutrition of apple. Ph.D Thesis submitted to Dr. Y.S. Parmar University of Horticulture and Forestry, Solan, India.

Kaith, N.S. and Awasthi, R.P. (1998) Effect of $\mathrm{K}$ on growth, yield, fruit quality and leaf nutrient status of apple Starking Delicious. Indian Journal of Horticulture 55(1): 10-15.

Kanwar, J.S. (1978) Investigation on pruning and fertilization requirement of peach (Prunus persica Batsch.) cv. Flordasun. Ph.D Thesis submitted to Punjab Agricultural University, Ludhiana, India.

Kumar, J., Kumar, R., Rai, R. and Mishra, D.S. (2015) Response of 'Pant Prabhat' guava trees to foliar sprays of zinc, boron, calcium and potassium at different plant growth stages. The Bioscan 10(2): 495-498.

Labanauskas, C.K., Embleton, T.W. and Jones, W.W. (1958) Influence of soil applications of nitrogen, phosphate, potash, dolomite and manure on the micronutrient content of avocado leaves. Proceedings of the American Society for Horticultural Science 71: 285-291.

Mehmood, A.S. (2003) Effect of fertigation practices on spur type apple varieties under high density plantation. M.Sc. Thesis submitted to Sher-e-Kashmir University of Agricultural Sciences and Technology of Kashmir, Shalimar, 
Srinagar, India.

Mishra, A.K., Kumar, S., Verma, S., Dubey, S. And Dubey, A.K. (2016) Effect of zinc sulphate, boric acid and iron sulphate on vegetative growth, yield and quality of strawberry (Fragaria $\mathrm{x}$ ananassa Duch.) cv. Chandler. The Bioscan 11: 2222-2225.

Rather, G.H. (2006) Combined influence of pruning regimes and fertilizer application on production and quality of apple (Malus x domestica Borkh.) cv. Red Delicious. PhD Thesis submitted to Sher-e-Kashmir university of Agricultural Sciences and Technology of Kashmir, Shalimar, Srinagar, India.

Shalan, A.M (2013) Performance of Vitis vinifera cultivar Flame Seedless grapevines under different node load per centimetre square of trunk crosssectional area. Asian Journal of crop
Science 5(2): 139-152.

Shoeib, M.M. and El-Sayed, H.A (2004) Response of Thompson Seedless grapevines to the spray of some nutrients and citric acid. Minia Journal of Agricultural Research and Development 20: 159-174.

Singh, D. and Singh, R (2002) Nitrogen nutrition of Peach-a review. Agricultural Review 23: 46-52.

Singh, G (2010) Effect of NPK on growth, yield and fruit quality of peach (Prunus persica L. Batsch). M.Sc. Thesis submitted to Punjab Agricultural University, Ludhiana, India.

Singh, N.P (1982) The studies on the nutrition of peach (Prunus persica Batsch.) cv. Flordasun in relation to pruning. M.Sc. Thesis submitted to Himachal Pradesh Krishi Vishwa Vidyalaya, Palampur, India.

\section{How to cite this article:}

Aroosa Khalil, M.K. Sharma, Nowsheen Nazir and Rifat Bhat. 2018. Effect of Budload and Fertilizer Application on Leaf Petiole and Fruit Nutrient Status of Grape cv. Sahebi. Int.J.Curr.Microbiol.App.Sci. 7(06): 1166-1173. doi: https://doi.org/10.20546/ijcmas.2018.706.138 